\title{
Laboratory preparedness to support the Covid-19 pandemic respond in Indonesia
}

DOI: https:// doi.org/10.22435/hsji.v11i2.4089

Ni Ketut Aryastami ${ }^{1}$, Harimat Hendarwan², Vivi Setiawaty ${ }^{3}$, Amir Su'udi $^{2}$, Ully Adhie Mulyani², Made Dewi Susilawati ${ }^{2}$, Syachroni², Nelly Puspandari ${ }^{3}$, Agus Suwandono ${ }^{4,5}$

${ }^{1}$ Center for Research and Development for Humanity and Health Management, National Institute of Health Research and Development Ministry of Health, Republic of Indonesia

${ }^{2}$ Center for Research and Development for Heath Resources and Services, National Institute of Health Research and Development Ministry of Health, Republic of Indonesia

${ }^{3}$ Center for Biomedical and Basic Health Technologies, National Institute of Health Research and Development Ministry of Health, Republic of Indonesia

${ }^{4}$ Indonesia One Health University Networking (INDOHUN)

${ }^{5}$ School of Public Health, University of Diponegoro, Semarang, Indonesia

Corresponding author : Ni Ketut Aryastami,

Email : aryastami@gmail.com

Received: October 29, 2020; Revised: November 30, 2020; Accepted: December 14, 2020

\begin{abstract}
Abstrak
Latar belakang: Penyakit jenis baru COVID-19 yang disebabkan oleh virus corona menjadi sebuah pandemic di akhir tahun 2019. Kota Wuhan (China) merupakan lokasi pertama terdeteksinya kasus COVID-19. Tanpa adanya kecurigaan apapun penyakit ini dengan cepatnya menyebar ke seluruh dunia mengikuti alur mobilitas manusia. Dalam kondisi tersebut sistem kesehatan di setiap negara tampak kelabakan khususnya dalam pengendalian transmisi penyakit. Studi ini ingin mengidentifikasi kesiapan jejaring laboratorium kesehatan di Indonesia.
\end{abstract}

Metode: Penilaian cepat dilakukan terhadap ketersediaan dan kesiapan laboratoriaum dalam pennanganan pandemi Covid-19. Pengumpulan data dilakukan melalui pengisian questioner yang dikirim secara elektronik. Waktu pelaksanaan adalah minggu ketiga dan keempat, Maret 2020. Terdapat 44 laboratorium jejaring laboratorium dibawah Kementerian Kesehatan yang menjadi subjek penelitian, dan sebanyak 33 yang merespon secara lengkap Variabel ketersediaan, kecukupan dan kebutuhan bahan dan alat.

Hasil: Jejaring laboratorium kesehatan dibawah Kementerian Kesehatan sudah terbentuk sejak tahun 2009. Dengan terjadinya pandemic COVID-19 Surat Keputusan Menteri Kesehatan telah direvisi hingga dua kali agar dapat meningkatkan kapasitas dan memperluas jejaring ke seluruh wilayah NKRI. Hasil studi menunjukkan, laboratorium jejaring dibawah Kementerian Kesehatan belum siap dalam menghadapi pandemic COVID-19. Dua jenis laboratorium jejaring yaitu laboratorium surveillans maupun laboratorium diagnostic memiliki kondisi yang sama. Ketersediaan bahan dan alat laboratorium standar masih tergolong rata-rata, bahkan dari sisi kecukupannyapun masih jauh dibawah kapasitas kebutuhan dalam penanganan specimen COVID-19. Kondisi yang sama juga tampak untuk bahan pendukung laboratorium termasuk alat pelindung diri untuk petugas.

Kesimpulan: Kesiapan laboratorium sebagai bagian dari system kesehatan dalam kondisi pandemic masih lemah. Keberadaan alat penunjang diagnose khususnya untuk penyakit menular harus dilengkapi sesuai dengann type laboratorium. Pandemi COVID-19 menjadi alarm dalam menghadapi era baru dan antisipasi masalah dimasa yang akan datang. (Health Science Journal of Indonesia 2020;11(2):140-8)

Kata kunci: Kesiapan laboratorium, COVID-19, Indonesia

\begin{abstract}
Background: A novel coronavirus disease called COVID-19 has become pandemic in late 2019. Wuhan City was the first place detected as the source of the pandemic. Without suspicion, it spreads over the world, along with human mobility. In such a condition, every country seems quite stuttering to prepare its health system to prevent its people from the possible transmission. This study aimed to describe the preparedness of the networking laboratory in Indonesia.

Methods: We conducted a rapid assessment of laboratory availability and preparedness to respond to the Covid-19 pandemic. We held the data collection on the third and fourth week of March 2020 by sending an electronic questionnaire to all 44 networking laboratories under the Ministry of Health structure. The variables assessed in this study were the availability and the requirements of the Covid-19 related laboratory's substances, including reagents and other equipment types.
\end{abstract}




\begin{abstract}
Results: The Ministry of Health established the networking laboratory in 2009, but due to the COVID-19 pandemic, it has renewed twice to enhance and expand the laboratory capacities over the country. Our studies showed preparedness among networking laboratories in Indonesia regarding this new emerging COVID-19 condition was quite devastating. Both surveillance and diagnostic laboratories have a similar situation. The availability of their primary materials was mediocre, but the adequacy was far beyond the capacity in handling the COVID-19 specimen. We found a similar case in the laboratory, supporting materials, and personal protective equipment (PPE).
\end{abstract}

Conclusion: Laboratory preparedness during initial period of time of the COVID-19 pandemic as part of the health system is still weak. The availability of the necessary equipment, supporting materials, and personal protective equipment are far beyond the requirements. The COVID-19 has alarmed the laboratory and the whole health system in Indonesia into a new era with better future preparedness. (Health Science Journal of Indonesia 2020;11(2):140-8)

Keywords: laboratory preparedness, COVID-19, Indonesia

The etiology of emerging COVID-19 as a new type of Corona Disease is unspecified yet when it started identified at Wuhan City, Hubei Province, China in late 2019. On January 7, 2020, China's scientist has called this new emerging disease caused by Severe Acute Respiratory Syndrome Coronavirus 2 (SAR-CoV-2). Along with the fast spread escalation of the case number, mortality, and import cases in other continents outside China, the WHO declared COVID-19 a public health emergency of international concern.

The role of the laboratory in examining the evidence of Covid-19 transmission is vital. The National Institute of Health Research and Development (NIHRD) under the Ministry of Health is appointed as the diagnostic center for COVID-19 samples. Indonesia faces a stuttering condition in handling this new pandemic as an immense archipelago consisting of more than 17 thousand islands with a 265 million population (CBS). ${ }^{1}$

The Indonesian Presidential Decree number 11/2020 on March 31 stated COVID-19 as Public Health Emergency in Indonesia. The escalation and spread of the disease over the country impacted not only the community health status and mortality but also economics, politics, sociocultural, and security defense. $^{2}$

Resilience planning has forced the central government to work hand in hand to cope with those cascading impacts encompassing the central budget. ${ }^{3}$ Following the President Decree, the first step of government preparedness was budget reallocation for the COVID-19 control program. The Ministry of the Finance Republic of Indonesia directly takes into action with the policy of all cost related to the procurement of medical devices supporting health examinations, isolation room, medical protective equipment; free of charge medical treatment for COVID-19 suspect, probable and positive cases including other prevention tools such as face mask, and others; which in consequences would swelling budget deficit of the country.

A rapid assessment is needed to enhance and empower laboratory networking concerning all costs related to medical devices' procurement supporting specimen examinations called laboratory preparedness. This assessment referred to the Ministry of Health $(\mathrm{MoH})$ Statement number HK.01.07/Menkes/214/2020 and HK.01.07/Menkes/216/2020. ${ }^{4}$ This study aimed to identify the laboratory preparedness to examine COVID-19 specimens so that the central government can improve the laboratory capacity and provide the specified devices needed.

\section{METHODS}

The study design was a Quantitative Study using a cross-sectional type of data collection. ${ }^{5}$ We intended this study as assessment research to empower and improve the existing laboratory's standard capacity of the laboratory for examining the COVID-19 specimens. A similar assessment at this data collection focusing on the laboratory capacity has published at the other journal. ${ }^{6}$

We conducted primary data collection to check the current availability of all equipment under study. The variables examined in this study were the availability and the requirements of the necessary materials such as reagents, viral transport media (VTM), and Dacron swab. We were also collecting the availability of supporting materials that are all components needed to do the viral examination. 
Personal protective equipment (PPE) such as hazmat suit, N95 face mask, google-glasses, etcetera; were also taken into account for this study variables.

We conducted this study in the 3rd to the 4th weeks of March 2020. The study location was 34 provinces in Indonesia involving 44 Laboratories in the networking categorized as National Referral Laboratories and Surveillance and Diagnostic laboratory. ${ }^{7}$

The data were collected using a standardized questionnaire sent over through emails, followed by a webinar discussion. The person in charge of the laboratories fulfilled the questionnaire, returning by application (email and WhatsApp). Clarification of the data done when there was unclear information given by the respondents. Data compiled by the researchers at the National Institute of Health Research and Development (NIHRD) Ministry of Health $(\mathrm{MoH})$ and Indonesia One Health University Networking (INDOHUN). Incoming data were entered into the data template and analyzed descriptively.
Ethical clearance provided by the Ethics Commission of the NIHRD, MoH under the letter number of LB.02.01/2/KE/303/2020.

\section{RESULTS}

Before we move on to the study results, let be understood first the differences of the functions and authorities of the National Referral Laboratory and the Diagnostic and Surveillance Laboratory based on the MoH Regulation number 658/Menkes/ Per/VIII/2009. ${ }^{5}$ The MioH updated this regulation during the COVID-19 pandemic with Indonesia's MoH number HK.01.07/Menkes/2020 concerning laboratory networking of Covid-19 examination. ${ }^{4}$ Both laboratories have a diagnostic function, but the National Referral Laboratory has broader authority to develop the standard operating procedure to be used by the Diagnostic Laboratory.

Table 1. The function of National Referral and Surveillance and Diagnostic Laboratory of COVID-19*

National Referral Laboratory

Receive specimens for COVID-19 assay from hospitals/ COVID-19 Diagnostic laboratory, health offices, and or other health laboratories

Develop standard operating procedures regarding the collection, management, and inspection of COVID-19 specimens

\section{Surveillance and Diagnostic Laboratory}

Receive specimens for COVID-19 assay from hospitals/COVID-19 Diagnostic laboratory, health offices, and or other health laboratories

Conduct screening checks on COVID-19 specimens using the form and standard operating procedures established by the Referral laboratory, i.e., the National Referral Laboratory under the National Institute of Health Research and Development, Ministry of Health.

Confirming the results of a positive COVID-19 assay conducted by the COVID-19 Diagnostic Laboratory and report to the Director-General of Disease Prevention and Control and the Director-General of Health Services with a copy to the Minister of Health

Quality assessment/Assurance/Control including technical supervision and guidance to COVID-19 Diagnostic Laboratory

Sending COVID-19 assay panel tests to COVID-19 Diagnostic Laboratory Send all specimens (after partly taken for assay) to the COVID-19 national referral laboratory immediately without waiting for the results of the assay

Send the assay results (positive and negative COVID-19) when ready, to the Center for Research and Development of Biomedical and Basic Health Technology, NIHRD, and the Public Health Emergency Operation Center (PHEOC), Directorate General of Disease Prevention and Control Ministry of Health.

Inform all the results to the hospital parallel to the Directorate General of Disease Control and Prevention and Provincial Health Office. Due to confidentiality, the positive assay's results can only be issued by the National Referral COVID-19Laboratory

Conduct technical supervision and guidance to the COVID-19 Provide feedback to hospitals/health services other health Diagnostic Laboratory

Perform recapitulation of assay's results from all COVID-19 laboratories if there is an error in the use of materials or media on the specimens received

Diagnostic Laboratories

* Indonesia MoH Regulation number 658/Menkes/Per/VIII/2009 
Indonesia is a big archipelago country consisted of 34 provinces. To deal with the laboratory issues on COVID-19, the MoH quickly setting up the coordination system through an official statement of the Minister of Health Number HK.01.07/
Menkes/182/2020. This statement pointed out 12 regional laboratories, and each laboratory responsible for two to six provinces depend on the distances and the area's width. Table 2 provides the regional laboratory and the areas under its responsibility. ${ }^{4}$

Table 2. Regionalization of the COVID-19 laboratory in Indonesia

\begin{tabular}{cll}
\hline No & \multicolumn{1}{c}{ Regional Laboratory } & \multicolumn{1}{c}{ Provinces under Responsibility } \\
\hline 1 & Jakarta Health Laboratory Center & Maluku, South Maluku, West Sumatera, North Sumatera, Aceh \\
\hline 2 & Palembang Health Laboratory Center & $\begin{array}{l}\text { Bengkulu, Bangka Belitung, South Sumatera, Jambi, Lampung } \\
\text { Gorontalo, North Sulawesi, West Sulawesi, Central Sulawesi, } \\
\text { South Sulawesi, South-East Sulawesi }\end{array}$ \\
\hline 4 & Makassar Health Laboratory Center & $\begin{array}{l}\text { South Kalimantan, Central Kalimantan, North Kalimantan, } \\
\text { East Kalimantan }\end{array}$ \\
\hline 5 & Purabaya Health Laboratory Center & Papua and West Papua \\
\hline 6 & $\begin{array}{l}\text { Jakarta Center for Environmental Health Engineering and } \\
\text { Disease Control Engineering }\end{array}$ & Riau, Riau Isles, West Java, West Kalimantan, Banten \\
\hline 7 & $\begin{array}{l}\text { Surabaya Center for Environmental Health Engineering and } \\
\text { Disease Control Engineering }\end{array}$ & Bali, East Java, East Nusa Tenggara, West Nusa Tenggara Barat \\
\hline 8 & $\begin{array}{l}\text { Yogyakarta Center for Environmental Health Engineering } \\
\text { and Disease Control }\end{array}$ & Yogyakarta and Central Java \\
\hline 9 & DKI Jakarta Regional Health Laboratory & DKI Jakarta \\
\hline 10 & Eijkman Institute for Molecular Biology & DKI Jakarta \\
\hline 11 & Faculty of Medicine of Indonesia University & $\begin{array}{l}\text { Central Hospital Dr. Cipto Mangunkusumo and Hospital of } \\
\text { Indonesia University }\end{array}$ \\
\hline 12 & Faculty of Medicine Airlangga University & $\begin{array}{l}\text { Provincial Hospital of Dr. Soetomo and } \\
\text { Hospital of Airlangga University }\end{array}$ \\
\hline
\end{tabular}

By March 25, 2020, there are 69 health laboratories distributed over the country. Among these laboratories, 44 laboratories having the capacity for COVID-19 surveillance and diagnostic, and the remaining 25 laboratories haven't yet such capacity.

\section{General condition of the laboratories providing the COVID-19 assays}

Among the 44 networking laboratories, 37 laboratories were fulfilled and sent back the questionnaire. Among those, 11 laboratories $(29,7 \%)$ acted as surveillance laboratories and the remaining $26(70,3 \%)$ as examiner laboratories. Nevertheless, some laboratories did not fill out the questionnaire that considered as missing data. Results found the mean capacity of specimen assay per day was 55 specimens with the same mode and median values of 48 . From the 44 networking laboratories total estimated specimen assay per-day that can be conducted all over the country until March 25, 2020, was 4293 specimens. The surveillance laboratory had a higher mean capacity of 70,3 compare to 48 specimen examination for the diagnostic laboratory. Those laboratories depended on the laboratory's human resources, both on their education and training experiences. All 33 laboratories fulfill the questionnaires, $76.5 \%$ of the laboratory's human resources having technical skills in a virus laboratory assay. Concerning these skills, of the ten surveillance laboratories, all human resources $(100 \%)$ had virus examination training skills compared to $66.7 \%$ of those in 24 diagnostic laboratories.

\section{The availability and adequacy of laboratory's basic materials of COVID-19 assay}

Lessons learned from the H5N1 epidemic in 2007 became references in assessing the laboratory capacity in Indonesia. The basic and necessary materials referred to the reagent, viral transport media (VTM), and Dacron nasal swab. Our study found that almost all of the 33 laboratories in this study have those. 
Table 3. The availability and adequacy of laboratory's basic materials of Covid-19

\begin{tabular}{|c|c|c|c|c|c|c|}
\hline \multirow{2}{*}{ No } & \multirow{2}{*}{ Basic Materials } & \multirow{2}{*}{$\mathrm{N}$} & \multicolumn{2}{|c|}{ Availability } & \multicolumn{2}{|c|}{ Adequacy } \\
\hline & & & $\mathrm{n}$ & $\%$ & $\mathrm{n}$ & $\%$ \\
\hline 1 & Reagent & 33 & 10 & 30.3 & 1 & 3.8 \\
\hline 2 & Viral Transport Media (VTM) & 33 & 21 & 61.8 & 4 & 15.4 \\
\hline 3 & Dacron swab & 33 & 19 & 57.6 & 2 & 7.7 \\
\hline
\end{tabular}

Table 4. Percent availability and adequacy of laboratory's basic materials of COVID-19 between surveillance and diagnostic's laboratory

\begin{tabular}{|c|c|c|c|c|c|c|}
\hline \multirow{2}{*}{ No } & \multirow{2}{*}{ Basic Materials } & \multirow{2}{*}{$\mathrm{N}$} & \multicolumn{2}{|c|}{ Surveillance Laboratory } & \multicolumn{2}{|c|}{ Diagnostic Laboratory } \\
\hline & & & Availability (\%) & Adequacy (\%) & Availability (\%) & Adequacy (\%) \\
\hline 1 & Reagent & 33 & 55.6 & 0 & 20.8 & 5 \\
\hline 2 & Viral Transport Media (VTM) & 33 & 55.6 & 16.7 & 64 & 15 \\
\hline 3 & Dacron swab & 33 & 55.6 & 16.7 & 58.3 & 5 \\
\hline
\end{tabular}

Table 3 depicted the laboratories' limited availability of necessary materials intended to assay the COVID-19 specimens, yet even limited in its adequacy.

Table 4 indicated quite a different percentage of availability and adequacy of the necessary materials for both types of laboratories. Comparing the availability and adequacy of supporting materials for COVID-19 between the surveillance and the diagnostic laboratory was a bit different. The surveillance laboratory has better adequacy than the diagnostic one.

\section{The availability and adequacy of laboratory's supporting materials of COVID-19 assay}

Supporting components are essential for laboratory testing. The laboratory preparedness on supporting materials on Covid-19 assay was based on the past evidence of the H5N1 epidemic. Table 5 showed the types, availability, and adequacy of the supporting materials at the laboratories under study.

Table 5. The availability and adequacy of laboratory’s supporting materials of COVID-19

\begin{tabular}{|c|c|c|c|c|c|c|}
\hline \multirow{2}{*}{ No } & \multirow{2}{*}{ Basic Materials } & \multirow[b]{2}{*}{$\mathrm{N}$} & \multicolumn{2}{|c|}{ Availability } & \multicolumn{2}{|c|}{ Adequacy } \\
\hline & & & $\mathrm{n}$ & $\%$ & $\mathrm{n}$ & $\%$ \\
\hline 1 & Micro pipet & 32 & 30 & 93,8 & 14 & 58,3 \\
\hline 2 & Micro-centrifuge refrigerator & 32 & 23 & 71,9 & 10 & 45,5 \\
\hline 3 & Water bath & 33 & 22 & 66,7 & 13 & 56,5 \\
\hline 4 & Vortex Mixer & 33 & 29 & 87,9 & 10 & 43,4 \\
\hline 5 & Freezer reagent -20 & 33 & 27 & 81,8 & 22 & 81,5 \\
\hline 6 & Freezer sample -20 & 33 & 24 & 72,7 & 18 & 66,7 \\
\hline 7 & Cryotube & 30 & 19 & 63,3 & 2 & 8,3 \\
\hline 8 & Ice pack & 33 & 30 & 88,2 & 7 & 28,0 \\
\hline 9 & Micro-centrifuge tube $1,5 \mathrm{~mL}$ & 31 & 25 & 80,6 & 5 & 26,3 \\
\hline 10 & PCR tube & 27 & 16 & 59,3 & 3 & 14,3 \\
\hline 11 & Aerosol barrier micropipette tips $1000 \mathrm{uL}$ & 30 & 19 & 63,3 & 3 & 14,3 \\
\hline 12 & Aerosol barrier micropipette tips $200 \mathrm{uL}$ & 30 & 19 & 63,3 & 3 & 14,3 \\
\hline 13 & Aerosol barrier micropipette tips $10 \mathrm{uL}$ & 30 & 17 & 56,7 & 3 & 14,3 \\
\hline 14 & RNA extraction kits & 30 & 10 & 33,3 & 1 & 4,3 \\
\hline 15 & Para-film & 31 & 22 & 71,0 & 6 & 26,1 \\
\hline 16 & UN Transport box & 31 & 9 & 29,0 & 5 & 20,8 \\
\hline 17 & Alcohol 70\% & 30 & 21 & 70 & 4 & 17,4 \\
\hline 18 & Biohazard plastic & 31 & 21 & 67.7 & 3 & 13,6 \\
\hline
\end{tabular}


Table 5 depicted the availability and adequacy of supporting materials for COVID-19. Most of the availability was relatively good except for the RNA extraction kits and UN Transport box, which were only $33.3 \%$ and $29 \%$, respectively. However, the adequacies were unexpectedly low, and only for the first six equipment showed the percentage of slightly more or less than $50 \%$

\section{The availability and adequacy of Personal Protective Equipment (PPE) for laboratory}

Biosafety and biosecurity are an essential standard for networking laboratories. The laboratory technical staff has to be protective safely when managing the assay such a contagious substance or specimen of COVID-19. The personal protective equipment refers to the Hazardous material suit (Hazmat), hair cap, boot shoes or shoe protective gear, appropriate masker a like N95, gloves as well as google glasses. Table 6 provides the availability and adequacy of such equipment.

Table 6 showed the personal protective equipment (PPE) availability at the laboratories was quite good, although it has scared inadequacy. Hazmat suit was available at half of the total laboratory under study. Shoes protective gear was barely available. From the table, it can be seen that the adequacy of all those equipment was very poor.

Table 6. The Availability and Adequacy of Personal Protective Equipment in Laboratory

\begin{tabular}{|c|c|c|c|c|c|c|}
\hline \multirow{2}{*}{ No } & \multirow{2}{*}{ Basic Materials } & \multirow{2}{*}{$\mathrm{N}$} & \multicolumn{2}{|c|}{ Availability } & \multicolumn{2}{|c|}{ Adequacy } \\
\hline & & & $\mathrm{n}$ & $\%$ & $\mathrm{n}$ & $\%$ \\
\hline 1 & Hazmat suit & 35 & 17 & 48.6 & 2 & 7.1 \\
\hline 2 & Other types of laboratory suit & 32 & 18 & 56.3 & 2 & 8 \\
\hline 3 & N95 Face Mask & 36 & 31 & 86.1 & 3 & 10 \\
\hline 4 & 3-ply surgical mask & 32 & 30 & 93.8 & 3 & 11.5 \\
\hline 5 & Google glasses & 36 & 30 & 83.3 & 5 & 17.2 \\
\hline 6 & Gloves & 34 & 33 & 97.1 & 5 & 17.9 \\
\hline 7 & Boot shoes & 34 & 21 & 61.8 & 4 & 14.3 \\
\hline 8 & Shoes protective gear & 34 & 10 & 29.4 & 2 & 6.9 \\
\hline 9 & Hair cap & 32 & 18 & 56.3 & 6 & 23.1 \\
\hline
\end{tabular}

\section{DISCUSSION}

The laboratory preparedness in Indonesia at the early pandemic of Covid-19 is relatively struggling. The primary and supporting equipment was far from adequate both at the diagnostic and surveillance laboratories. Procurement of primary and supporting the laboratory's material and personal protective equipment (PPE) enhanced the laboratory capacity for the COVID-19 pandemic. Reallocation of the government budget in laboratory capacity for COVID-19 covered three budget sources; first, refocusing budget at each laboratory; second, budget allocation from the province as well as district and municipality; and third, the budget of the central government as well as the third party such as international agencies, community, and private sectors. The central government and the thirdparty budget delivered to the National Task Force of COVID-19 for the acceleration of COVID-19 pandemic control at the national, province, and district/city levels.

One of the five critical actions done during the surge pandemic situation is a better preparedness of the health system. In Indonesia, the central government quickly took action since the Covid-19 declared a national pandemic. A national action group called Gugus Tugas developed at the national until village level. These groups worked and concerned with the social situation to maintain community health and prevent Covid-19 transmission. At the central level, the Gugus Tugas also helped maintain the laboratory preparedness, such as distributing the laboratory equipment simultaneously with the other things delivered by the NIHRD. These actions accordance with the expert thought as mentioned by Lancet. ${ }^{8}$

The availability and adequacy of basic and supporting laboratory materials for COVID-19 assay are fulfilled adequately either at the surveillance or diagnostic laboratories - the availability of reagents for RNA extraction and PCR kits prioritized by the laboratory refocusing the budget. Also, the Ministry of Health and Central Government involved the nongovernment laboratories such as universities and private laboratories as diagnostic laboratories based on the Circular Latter of the Ministry of Health on April 7, 2020. RT-PCR, as well as guideline on SARS$\mathrm{CoV}-2$ testing, are equipped these laboratories. ${ }^{9}$ 
The surge of the COVID-19 pandemic made the Indonesian health system stuttering. The patient buildup in hospitals simultaneously with the swab specimen is queued at the laboratories. An alternate rapid diagnostic test (RDT) was utilized to screen the COVID-19 suspects and prevent such conditions, in addition to waiting for the supply of PCR kits. The test took the blood specimen's fingertip to detect IgG and IgM antibodies as signs of infection. This test procedure was more applicable for mass screening among people at risk, such as those having contact history with a positive case of COVID-19, COVID-19 suspects, and the health worker in hospitals. Yet this RDT that had been widely used at Jakarta's cluster area Jakarta was more likely to give a false-positive result. Therefore, a positive RTD result then still be confirmed and followed by PCR assay for robust diagnosis. ${ }^{10}$

The Center of Research and Development for Biomedical and Basic Health Technology, NIHRD provides and distributes other basic material such as viral transport material (VTM) and Dacron nasal swab. Nonetheless, for further rapid prevention, the Dacron swab's limitation was temporarily replaced by the Diphtheria nasal swab as long as this nasal swab stick was not made by wood and cotton bulb.

The availability and adequacy of supporting materials for COVID-19 comparing to handle the epidemic of Avian Influenza (H5N1). Utmost the laboratories had the materials respectively, but they were in minimal numbers. In the hospital's laboratory, the pseudo materials unavailability or inadequacy was not a problem as they can directly request from the hospital's supporting medic division at any time. The previous experienced told us the essential to conduct the laboratory assessment for new emerging and re-emerging diseases. However, it was unfortunate that the laboratory networking developed in 2009 was still tricky to accomplish the laboratory task and readiness when a new-emerging pandemic such as COVID-19 happened. This situation was again evident after the outbreak of H5N1. ${ }^{11}$

The availability of personal protective materials was minimal at the laboratories under this study. The estimation of the standard requirement was far beyond the adequacy. For the contagious specimen assay, PPE was absolute and standardized. The availability of a Hazmat suit and hair cap approximately only $48-56 \%$ for all laboratories under this study. They neglected availabilities of boot and shoes protective gear. Other PPE availability such as masker, gloves, and google glasses were far from required. The technical laboratory persons should implement all biosafety required including PPE for virus examination and utilize laboratory algorithm of SAR-CoV2 as recommended by WHO. ${ }^{12}$

The standard number of PPE needed varied depending upon the capacity of the laboratory. WHO did not address the PPE standard for laboratory, but hospital and patients. For patients per day, the PPE needed were: gown and medical mask (25 units), gloves - non-sterile (50 units), and google-glass or face shield (1 unit). ${ }^{13}$

Supporting assay devices is urgently in need either at the surveillance or examiner of COVID-19 laboratory. It was evident that all of the networking laboratories had standard supporting materials. Nonetheless, the adequacy, based on the laboratory's capacity assay estimation was far beyond the standard referring to an overview by Taipe's scientists, saying that for diagnosis on Covid-19, a well-equipped laboratory having level 3 biosafety level. ${ }^{14}$ Nevertheless, a well-equipped laboratory is not merely the important things, but a well documentation of infected cases are simultaneously in need to prevent the transmission of the Covid-19. ${ }^{15}$

In conclusion, the laboratory's networking was developed in 2009. However, in this new pandemic of COVID-19 evident, lack of laboratory preparedness was portrayed at the early time of pandemic evidence in March 2020. The existing laboratory networking seemed to lack maintenance. However, based on study findings, the central government rapidly tackled problems for helping Indonesia's society control the COVID-19 pandemic. The networking system was officially rapidly expanded. The government also set budget refocusing for laboratory hard-wares and soft-wares. This policy prioritized all costs related to the procurement of laboratory and medical devices.

The basic materials barely available in the laboratories under study include reagents, viral transport media, Dacron swab, and other supporting materials. The government quickly fulfills all the required devices identified in this study either by local or imported products. By April 15, 2020, the number of the laboratory capable of doing COVID-19 assays using RT-PCR increased by more than 70 laboratories compared to 44 laboratories when this study carried out. Although the numbers of those laboratories kept growing up, it was still a significant homework for Indonesia to maintain the laboratory capacity to dawn recent and future pandemics. 


\section{Study limitation}

This paper focused on the laboratory's preparedness, equipment availability, and stuff, excluding human resources. This study kept going to leverage the need for human resources in escalating the laboratory capacity during the surge of Covid-19 pandemics as already published in the other journal. ${ }^{6}$

\section{Acknowledgments}

We thank the Center of Research and Development for Health Resource and Services, NIHRD, MoH, for the permit and encouragement to conduct this rapid study amid the COVID-19 pandemic, March 2020. We also thank the Networking Laboratory that participated in this study. Finally, we thank all supporting team, Dyah Armi, Elvira Eka Putri, and Indira Wahyuni, to complete the study.

\section{Funding}

Indonesia's government budget supported this study through the NIHRD, MoH of the Republic of Indonesia.

\section{Availability of the data and materials}

All data kept protected by the Data Management Section at the NIHRD, MoH, Republic of Indonesia.

\section{Author contribution}

NKA is the coordinator of this study under the research umbrella investigated by HR. Both NKA and HR have an equal contribution to this article.

\section{Competing interest}

We declare that there is no competing interest in this study

\section{Consent for publication}

Not applicable

\section{Ethics approval}

Exempted ethical clearance declared by The Ethical Committee, NIHRD, MoH, Republic of Indonesia number LB.02.01/2/KE/303/2020.

\section{REFERENCES}

1. Statistical yearbook of Indonesia 2019. Jakarta: Statistics Indonesia; 2019 [Cited 2020 August 24). Available from: https://www.bps.go.id/publication/2019/07/04/ daac1ba18cae1e90706ee58a/statistik-indonesia-2019. html. Indonesia's Secretariat Ministry 2020.

2. President Statement 'Keppres' number 11/2020 about Public Health Emergency on Covid-19. Jakarta, March 31, 2020.

3. Brown A, Horton R. A planetary health perspective on COVID-19: a call for papers. Lancet Planet Health. 2020. Published Online April 3, 2020. https://doi. org/10.1016/ S2542-5196(20)30078-4.

4. Indonesia's Ministry of Health 2020. Minister of Health Statement 'Keputusan Menteri Kesehatan' number HK.01.07/Menkes/2020 about laboratory networking of Covid-19 examination. Jakarta, March 19, 2020.

5. Creswell JW. Research approach: qualitative, quantitative, and mixed methods approach. Fourth ed. California: SAGE Publication inc; 2014.

6. Hendarwan H, Syachroni S, Aryastami NK, Su'udi A, Susilawati ND, Despitasari M, Mulyani UA, Sumiarsih M, Puspandari N, Indrati AR, Solikha DA, Riana DA, Wahyuni IR. Assessing the COVID-19 diagnostic laboratory capacity in Indonesia in the early phase of the pandemic. WHO South-East Asia Journal of Public Health. September 2020, 9(2) IP: 114.5.249.138.

7. Indonesia's Ministry of Health. Minister of Health Regulation 'Peraturan Menteri Kesehatan number 658/ Menkes/Per/VIII/2009' about diagnostic laboratory networking new-emerging and re-emerging disease. 2009.

8. Horton R. Offline: Covid-19-what countries must do. www.thelancet.com. Vol 395, April 4, 2020. [Cited 2020 April 7].

9. Ministry of Health Republic of Indonesia. Circular Letter of the Minister of Health of the Republic of Indonesia HK.02.01/Menkes/234/2020. Guidelines for the SARS-CoV-2 real-time polymerase chain reaction (RT-PCR) test for laboratories in hospitals and other laboratories carrying out testing for coronavirus disease 2019 (COVID-19)]. Jakarta; 2020 [Cited 2020 August 17]. Available from: https://gugustugas.riau. go.id/uploads/SE\%20MENKES\%20NOMOR\%20 234\%20TAHUN\%202020.pdf.

10. Hong KH, Lee SW, Kim TS, et al. Guidelines for Laboratory Diagnosis of Coronavirus Disease 2019 (COVID-19) in Korea. 2020. Available from: https:// doi.org/10.3343/alm.2020.40.5.351.

11. Setiawati V, Pangesti KNA, Sampurno OD. Establishing a laboratory network of influenza diagnosis in Indonesia: an experience from the avian flu (H5N1) outbreak. Clinical Epidemiology 2012:4;209-12.

12. PAHO and WHO. Requirements and technical specifications of personal protective equipment (PPE) for the novel coronavirus (2019-ncov) in healthcare settings. 2020. (interim recommendations, 2/6/2020).

13. Pan American Health Organization / World Health Organization. Epidemiological update: novel coronavirus (COVID-19). February 28, 2020, Washington, D.C.: 
$\mathrm{PAHO} / \mathrm{WHO} ; 2020$

14. Wu Y, Chen C, Chan Y. The outbreak of COVID-19: an overview. J Chin Med Assoc. <doi: 10.1097/ JCMA.0000000000000270>. www.ejcma.org. [Cited: 2020 April 30].
15. Li R, Pei S, Chen B, Song Y, Zang T, Yang W, Shaman J. Substantial undocumented infection facilitates the rapid dissemination of novel coronavirus (SARS-CoV-2). Science 368, 489-493. 1 May 2020. Available from: https://science.sciencemag.org/content/sci/368/6490/489. full.pdf 